\title{
An IPM Program for Managing Fungal Leaf Blight Diseases of Carrot in New York
}

\author{
B. K. Gugino, J. E. Carroll, T. L. Widmer, P. Chen, and G. S. Abawi, Department of Plant Pathology, Cornell \\ University, New York State Agricultural Experiment Station, Geneva 14456
}

\begin{abstract}
Gugino, B. K., Carroll, J. E., Widmer, T. L., Chen, P., and Abawi, G. S. 2007. An IPM program for managing fungal leaf blight diseases of carrot in New York. Plant Dis. 91:59-65.

Fungal leaf blight diseases caused by Cercospora carotae and Alternaria dauci occur annually on processing carrot in New York, with growers applying up to eight fungicide sprays to manage these diseases. An integrated pest management (IPM) program involving the use of a $25 \%$ disease incidence threshold to prompt the first fungicide application and timing subsequent sprays by monitoring for increases in disease severity and weather forecasts in conjunction with a 10- to 14-day spray interval was evaluated in grower fields in 1997 and 1998. The IPM plots, compared with the grower plots, required two to six fewer fungicide applications but showed no yield reduction. From 1999 to 2004, the IPM program was validated and the effect of crop rotation and carrot cultivar susceptibility also were assessed. Carrot plants growing in fields with 2-year or longer crop rotation intervals reached the $25 \%$ disease incidence threshold later in the season and required fewer fungicide applications. The less-susceptible carrot cultivars also reached the $25 \%$ disease incidence threshold later, required fewer fungicide applications, and were less severely diseased than more susceptible cultivars. Validation of the IPM program in New York showed that both fungal leaf blights can be managed effectively using a $25 \%$ incidence threshold to prompt the first fungicide spray and making the subsequent fungicide applications based on increases in disease severity, weather forecasts, and a 10- to 14-day spray interval.
\end{abstract}

Additional keywords: disease threshold, scouting

Leaf blight diseases caused by Alternaria dauci (Kühn) Groves \& Skolko and Cercospora carotae (Pass.) Solheim are a major constraint to the production of processing carrot (Daucus carota L. var. sativus Hoffm.) in New York (14) and potentially affect $100 \%$ of the carrot crop every year (35). These diseases are particularly severe when they occur early in the season and are ineffectively managed. Losses result from reduced photosynthetic area, and breakage or separation of weakened foliage and petioles from the root during mechanical harvesting, so that roots remain in the ground. Cercospora leaf blight lesions are cream to gray colored with dark

Corresponding author: George S. Abawi

E-mail: gsa1@cornell.edu

Current address of J. E. Carroll: New York State Integrated Pest Management Program, Cornell University, NYSAES, Geneva 14456.

Current address of T. L. Widmer: United States Department of Agriculture-Agricultural Research Service, Foreign Disease and Weed Science Research Unit, Fort Detrick, MD 21702.

Current address of P. Chen: Department of Plant Pathology, National Chung-Hsing University, Taichung, Taiwan, 402.

Accepted for publication 24 August 2006.

DOI: 10.1094/PD-91-0059

(C) 2007 The American Phytopathological Society definitive margins, circular in shape on the leaf lamina or more elongate on the leaf margin, and more commonly found on younger leaves $(17,34)$. Lesions on petioles have a lighter tan center $(23,33)$. Alternaria leaf blight lesions are brown to black in color, irregularly shaped, occur on the margins and tips of carrot leaflets as well as petioles, and more commonly are found on older leaves $(17,30)$. Under conditions of favorable temperature (16 to $25^{\circ} \mathrm{C}$ for $\mathrm{A}$. dauci and 20 to $28^{\circ} \mathrm{C}$ for $\mathrm{C}$. carotae) and prolonged hours of leaf wetness $(7,9,31)$, the lesions of both pathogens will become numerous, expand, coalesce, and blight leaves. $(9,31,33)$.

Both leaf blight pathogens can spread through infected or contaminated seed $(20,21,33)$, infect Queen-Anne's-lace ( $D$. carota L.) and other Daucus spp. (9), and survive on crop residue (22). However, neither pathogen can survive long in soil without host tissue. The length of time the crop residue persists in the soil depends on soil type and climate, whereas the rate of spread of these diseases in the field depends on the initial level of inoculum, air temperature, and the presence of water from rain, irrigation, high humidity, or dew (22). Therefore, through reducing initial inoculum, crop rotation can be an effective management option for growers; in New York, a 2-year rotation out of carrot is recommended. Planting cultivars with some degree of leaf blight resistance also can aid in disease management, because such cultivars can reduce the rate of disease spread and slow the progress of the epidemic (10). Carrot germ plasm and cultivars with varying levels of resistance to these diseases have been reported $(15,24-26)$ and the inheritance of resistance has been documented (1).

To enable more timely application of fungicides for Alternaria leaf blight, Gillespie and Sutton developed a disease risk model based on temperature and leaf wetness duration and its known effects on pathogen sporulation, spore germination, disease development, and secondary spread $(11,18,29)$. As mean temperature increased, infection occurred with fewer hours of leaf wetness on susceptible cultivars; however, longer periods of leaf wetness were required on moderately resistant cultivars (32). The predictive scheme of Gillespie and Sutton (11) utilized a threshold of 1 to $2 \%$ of the leaf surface symptomatic (disease severity) that corresponded to $25 \%$ of leaves with one or more lesions (disease incidence) to prompt the first fungicide application (32). Subsequent fungicide applications were based on forecasted weather that was favorable for pathogen infection and a minimum spray interval of 7 to 10 days.

The primary objective of this study was to develop an effective integrated pest management (IPM) program for carrot fungal leaf blight diseases in New York that focused on scouting each cultivar block in a field and using a disease incidence threshold for application of the first fungicide. Specifically, the effectiveness of the $25 \%$ disease incidence threshold $(11,32)$ for Alternaria leaf blight was validated under New York conditions and also tested for Cercospora leaf blight. The impact of length of crop rotation and cultivar susceptibility on reaching the $25 \%$ threshold also was assessed. Preliminary reports have been published previously $(8,12,13)$.

\section{MATERIALS AND METHODS}

Evaluation of the $25 \%$ disease incidence threshold in commercial fields. In 1997 and 1998, one scouted plot (IPM plot) was established in each of four and five commercial carrot fields in the Lake Ontario Plains and Potter Muck agroecosystems, respectively, on mineral and organic soils in New York. The size of the IPM plots ranged from 1.2 to 7.3 ha depending on the size of the commercial 
field. The remainder of each field was designated as the grower plot. All plots were maintained by the collaborating grower according to their standard program (i.e., cultural practices, fertilizers, and pesticide applications), with the exception of the fungicide sprays. In the IPM plots, the first fungicide application was made when disease incidence reached the $25 \%$ threshold level. Subsequent fungicide applications in the IPM plots were based on weekly scouting for an increase in disease severity in combination with the forecasted weather, as developed by Gillespie and Sutton (11). Forecasted weather conditions were considered favorable when the chance of rain was greater than $30 \%$ coupled with night temperatures greater than $16^{\circ} \mathrm{C}$. Weather data from the New York State IPM Program, Network for Environment and Weather Awareness (NEWA) and Accuweather Service were used depending on availability and scouter preference. Fungicide applications in the grower plots were made according to the collaborating grower's standard fungicide application program. Chlorothalonil (Bravo 720, 4.94 liters/ha; Syngenta Crop Protection, Greensboro, NC) was the only fungicide applied to either the IPM or growers' plots in 1997 and 1998. A 10-to 14-day spray interval, rather than the 7- to 10-day label recommendation, typically was observed in both the IPM and grower plots to reflect the spray intervals practiced by growers on processing carrot.
Field scouting and disease assessment. Each plot was scouted once a week in a Vor W-shaped transect starting from midJune to early July, depending on the onset of weather conditions that were favorable to pathogen infection. A minimum of 10 sampling stops were made and five leaves from five adjacent plants were examined at each stop for a total of 50 leaves per plot. A leaf was considered infected if one or more lesions caused by either A. dauci or C. carotae were observed, because growers manage both diseases without distinction with the same fungicide, chlorothalonil. The occurrence of 12 to 13 infected leaves in the IPM plots (25\% disease incidence) prompted recommendation of the first fungicide application. After the $25 \%$ threshold was reached, disease severity on a scale of 1 to 9 based on the percent leaf area symptomatic ( $1=0 \%$ tissues symptomatic, $2=$ up to $1 \%, 3=2$ to $5 \%, 4=6$ to $10 \%, 5=11$ to $20 \%, 6=21$ to $30 \%, 7=$ 31 to $40 \%, 8=41$ to $50 \%$, and $9=$ over $50 \%$ ) also was assessed on the same 50 leaves per plot. Area under the disease progress curve (AUDPC) values were calculated at the end of the season using the following formula: AUDPC $=\Sigma_{i<n}\left[\left(R_{i+1}+\right.\right.$ $\left.R_{i}\right) / 2$ ] $\left(t_{i+1}-t_{i}\right)$, where $R_{i}=$ disease severity rating (percent leaf surface blighted) at the $i$ th observation, $t_{i}=$ time (days) since the previous rating at the $i$ th observation, and $n=$ total number of observations (27). AUDPC values were compared using a two-sided $t$ test, $P \leq 0.05$ (SAS 9.0; SAS
Institute, Cary, NC) using the 10 sampling stops per plot per date to calculate error.

Yield measurements. From each IPM plot and grower plot, carrot plants were hand harvested from four randomly selected, 3-m-long sections of row and yield measurements were taken on 18 and 22 September 1997 and 23 September 1998. The total plant weight (1998 only) and total root weight were determined. Yield data from the IPM plots and the grower plots was compared and analyzed using a two-sided $t$ test $P \leq 0.05$ (SAS 9.0; SAS Institute).

Validation of the $25 \%$ threshold and impact of crop rotation and cultivar susceptibility. In each of the years 1999, 2000, 2001, 2002, 2003, and 2004, 3, 3, $13,11,3$, and 9 commercial carrot fields, respectively, were scouted weekly during the growing season as described previously to validate the use of the $25 \%$ disease incidence threshold in large-scale production fields. Weekly scouting was initiated once the weather conditions became favorable for pathogen infection, typically in midJune to early July. Application of the first fungicide was recommended once disease incidence reached the $25 \%$ threshold level and subsequent applications were recommended based on increases in disease severity, forecasted weather, and a 10- to 14day spray interval, as described above. In fields containing multiple cultivars, each cultivar was scouted individually to assess the impact of differences in fungal leaf
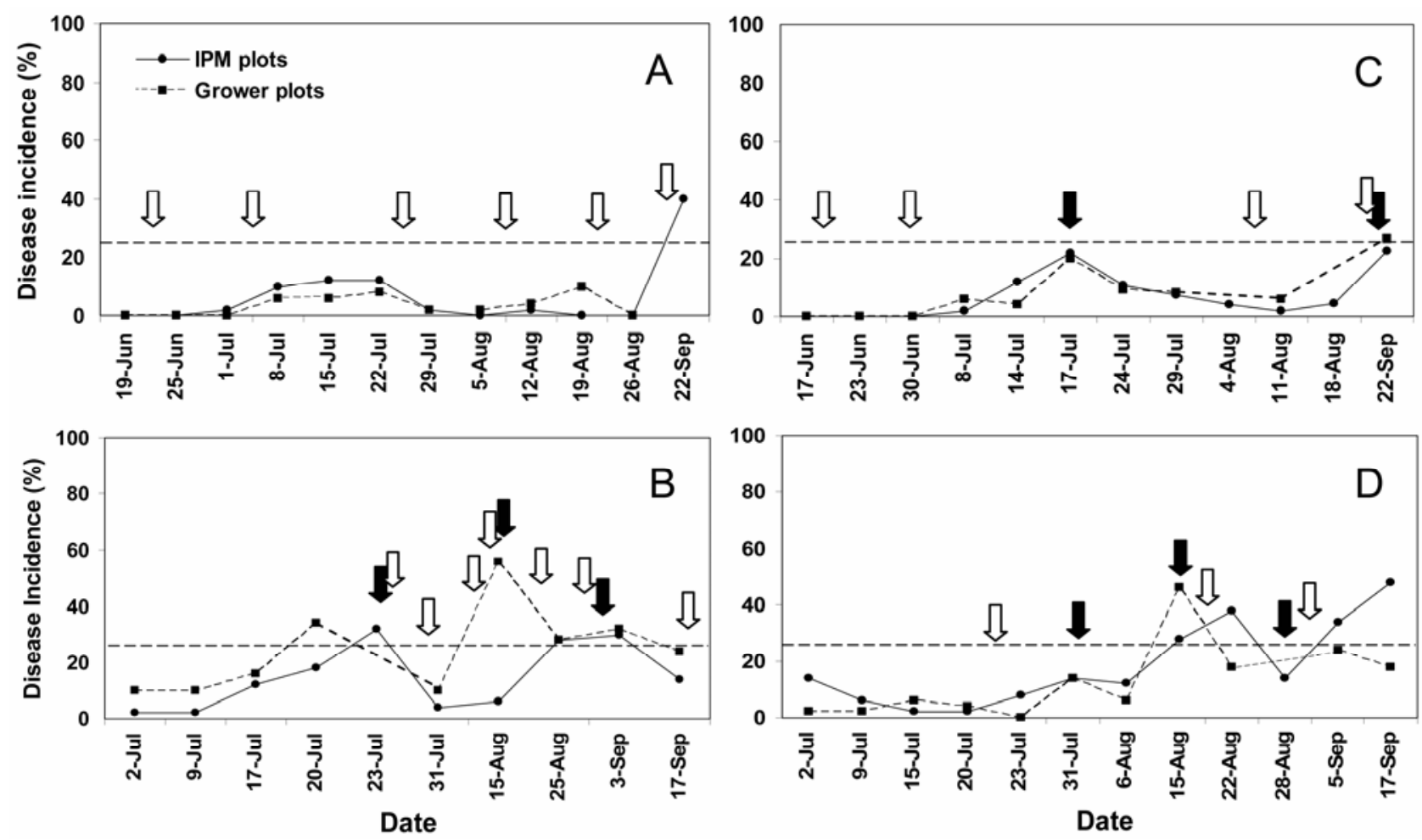

Fig. 1. Incidence of fungal leaf blight in integrated pest management (IPM) plots and grower plots in A, B, C, and D, four fields in 1997. Disease incidence (presence or absence of one or more lesions per leaf caused by either Alternaria dauci or Cercospora carotae) was determined by examining five leaves from five adjacent plants at 10 locations along a V- or W-shaped transect in each plot per field. The dotted horizontal line represents the $25 \%$ disease incidence threshold. The black and white arrows indicate when fungicide (chlorothalonil) applications were made to either the IPM plots or grower plots, respectively. 
blight susceptibility on when each cultivar reached the $25 \%$ threshold and on the AUDPC. Cropping histories of individual fields were collected in 2001, 2002, and 2004 to evaluate the effect of crop rotation on leaf blight disease incidence and severity. Grower fungicide spray records also were obtained in 2001, 2002, and 2004 to compare with the recommended sprays in the fungal leaf blight IPM program. The two fungicides applied were chlorothalonil (Bravo, various formulations; Syngenta Crop Protection) and azoxystrobin (Quadris, various formulations, or Amistar, various formulations; Syngenta Crop Protection) at label rates to manage both fungal leaf blight diseases depending on availability and grower preference. From 2001 to 2004, the occurrence of bacterial blight in some fields had a confounding effect on the IPM program for fungal leaf blights by increasing the number of copper sprays, which also help to manage fungal leaf blights. However, all spray applications were taken into account in the presentation of the results for fungal leaf blights. Data were analyzed using a Poisson regression to determine the effect of cultivar, year, crop rotation, and threshold date on the number of fungicide sprays applied. A linear model with normal error was used to determine the effect of cultivar, year, and crop rotation on the threshold date (SAS 9.0; SAS Institute).

\section{RESULTS}

Evaluation of the $25 \%$ disease incidence threshold in commercial fields. In 1997, three of the four IPM plots required six (Fig. 1A), four (Fig. 1B), and two (Fig. 1C) fewer chlorothalonil fungicide applications compared with the grower plots, which were sprayed according the grower's standard program. The fourth set of IPM and grower plots both were sprayed only three times (Fig. 1D). The IPM plot requiring six fewer sprays than the grower plot (Fig. 1A) did not exceed the $25 \%$ incidence threshold until late September and, therefore, no sprays were recommended. In two of the other IPM plots (Fig. 1C and D), a spray was recommended when $25 \%$ disease incidence threshold was approaching but had not yet been reached due to the forecasted weather conditions. In 1998, three of the five IPM plots required six (Fig. 2A), five (Fig. 2B), and four (Fig. 2C) fewer fungicide applications compared with the grower-managed plots. High disease incidence and severity were observed in one field in 1998 (Fig. $2 \mathrm{E}$ ) and, as a result, three to five more fungicide applications were required to manage fungal leaf blight in that field compared with the other fields evaluated that year.

Fungicide sprays applied in the IPM plots (black arrows) subsequent to the first spray were based on an increase in the disease severity rating (Fig. 1B, C, and D, second sprays shown) or based on length of the spray interval (Fig. 1B and D, third
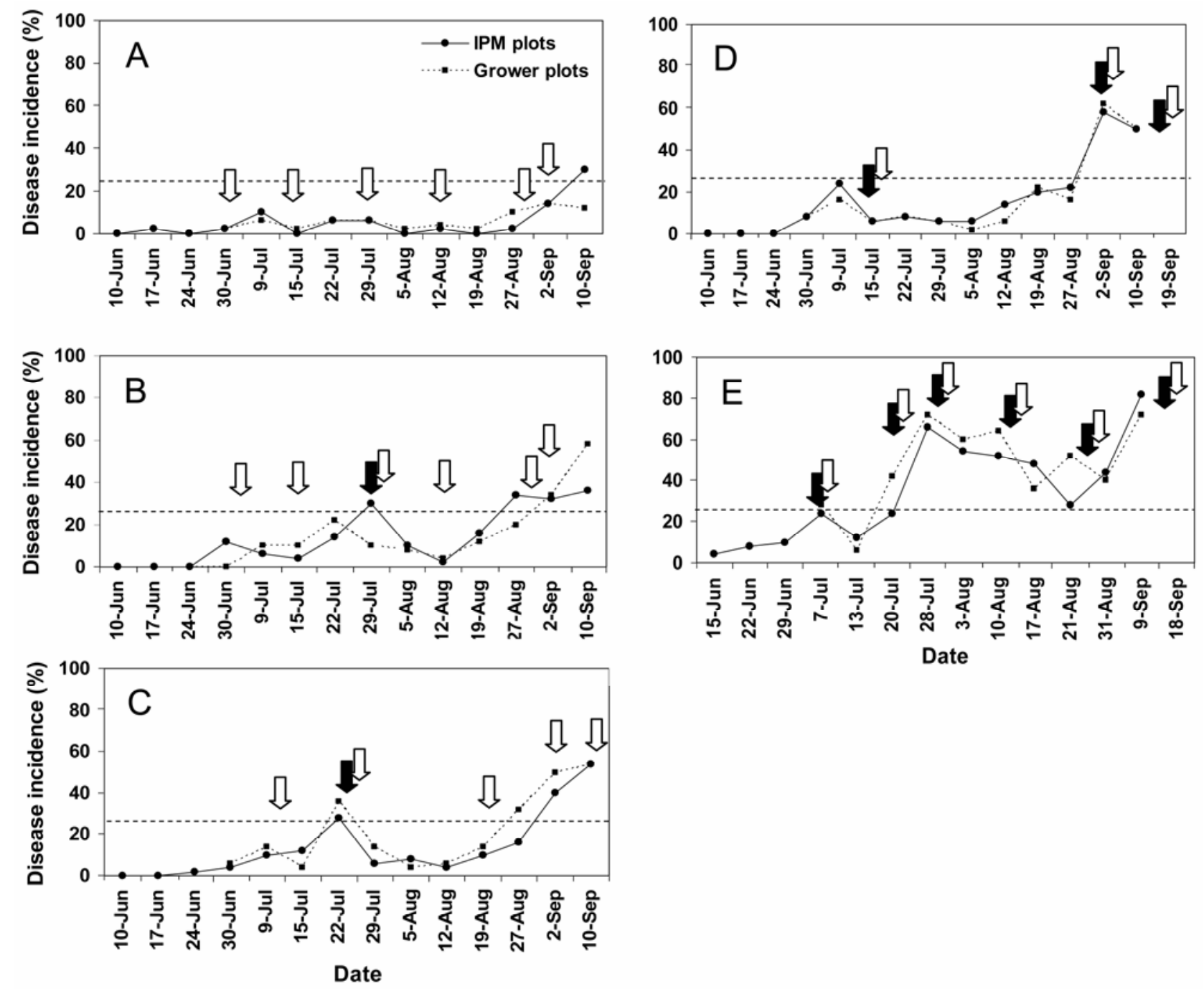

Fig. 2. Incidence of fungal leaf blight in scouted integrated pest management (IPM) and grower plots in A, B, C, D, and E, five fields in 1998. Disease incidence (presence or absence of one or more lesions per leaf caused by either Alternaria dauci or Cercospora carotae) was determined by examining five leaves from five adjacent plants at 10 locations along a V- or W-shaped transect in each plot of each field. The dotted horizontal line represents the $25 \%$ disease incidence threshold and the black and white arrows indicate when fungicide (chlorothalonil) applications made to the IPM plots and grower plots, respectively. A single carrot cultivar was grown in each field, as follows: A, Carson, B, Kamaran, C, Bolero, D, Boomer, and E, Eagle. 
spray). In all cases, forecasted weather conditions also were considered. For the six IPM plots that received fewer sprays than the grower plots in 1997 and 1998, no differences were found in the AUDPC values between these and the grower plots. Further, yield (t/ha) was not significantly different from that in the growermanaged plots except for one field in 1997 (Table 1).

Validation of the $25 \%$ threshold and impact of crop rotation and cultivar susceptibility. During the years 1999 to 2004, the fungal leaf blight IPM program was validated in 97 cultivar blocks from 42 fields belonging to the seven growers who collaborated on the project. We were able to obtain grower spray records for comparison with the IPM-recommended sprays for 69 of the 97 cultivar blocks. Of these, 35 were sprayed more than recommended, 27 were sprayed the same number of times as recommended, and 7 were sprayed fewer times than recommended. Over all years, an average of three sprays per season were recommended under the IPM program and an average of four sprays were applied by the collaborating growers, who were receiving the weekly IPM scouting reports. The leaf blight IPM program reduced the average number of growerapplied sprays by up to four sprays compared with the years prior to 1997, when growers were applying up to eight sprays per season.

For most cultivar blocks, the longer the field had been rotated out of carrot, the later in the season the $25 \%$ disease incidence threshold was reached and the fewer fungicide applications were required to manage fungal leaf blight diseases $\left(\chi^{2}=\right.$ $6.4, P=0.01$; Table 2). In 2002, the cv. Bergen reached the threshold on 1 July in a field rotated out of carrot for 1 year and on 12 August in a field rotated for 3 years. Long rotation out of carrot ( $\geq 20$ years) or planting in fields with no history of carrot cultivation proved advantageous in delaying the time the threshold was reached until mid-August through late September (Table 2), even for susceptible cultivars (15). The year had a significant effect on when the $25 \%$ disease incidence threshold was reached $(F=3.6, P=0.05)$. The hot and dry 2001 growing season delayed the $25 \%$ disease incidence threshold in fields rotated out of carrot for $\geq 2$ years, even for cultivars known to be susceptible to fungal leaf blights (i.e., Kamaran and Eagle). In contrast, the cool and wet 2004 growing season promoted disease development and fields reached threshold in early to midJuly, despite being rotated out of carrot for two or more years, except for the field with no history of carrot. In general, fields under short rotation reached threshold in July, whereas those with longer rotations ( $>2$ years) reached threshold in August or September $(F=3.8, P=0.07$; Table 2). However, in two cases, the same cultivar planted in a field with a longer rotation reached the $25 \%$ threshold earlier than in another field with a shorter rotation (Carson, 2001, 2-year rotation versus no rota-

Table 1. Yield (root weight) and area under the disease progress curve (AUDPC) comparisons between the grower plots and the integrated pest management (IPM) plots that received fewer chlorothalonil fungicide applications in three fields in 1997 and $1998^{\mathrm{w}}$

\begin{tabular}{clccc}
\hline Year, field & Treatment $^{\mathbf{x}}$ & No. of sprays & Root weight (t/ha) $^{\mathbf{y}}$ & AUDPC $^{\mathbf{z}}$ \\
\hline 1997 & & & & \\
A & IPM & 0 & $69.0^{*}$ & $\ldots$ \\
& Grower & 6 & 91.2 & $\ldots$ \\
B & IPM & 2 & 94.1 & 30.3 \\
& Grower & 4 & 107.1 & 32.3 \\
C & IPM & 3 & 47.9 & 98.1 \\
& Grower & 7 & 72.8 & 117.6 \\
1998 & IPM & 0 & 94.5 & 54.0 \\
A & Grower & 6 & 90.9 & 71.0 \\
& IPM & 1 & 93.2 & 100.0 \\
B & Grower & 6 & 89.1 & 100.0 \\
& IPM & 1 & 114.5 & 107.0 \\
& Grower & 5 & 121.9 & 108.0 \\
\hline
\end{tabular}

${ }^{\mathrm{w}}$ Carrot yield in 1997 fields A and B was determined on 22 September and in field C on 18 September. In 1998, yield was assessed on 23 September 1998.

${ }^{x}$ IPM plots were managed using a $25 \%$ disease incidence threshold to prompt the first fungicide application. The need for subsequent applications was based on increases in disease severity, forecasted weather, and length of spray interval. Grower plots were managed according to the growers' standard fungicide application schedules.

${ }^{y}$ Carrot plants in each plot were hand harvested from 3-m-long sections of each of four rows and total root weight determined. The asterisk $(*)$ denotes a significant difference between the root weight for the IPM and grower plots according to a two-sided $t$ test, $P \leq 0.05$, using the four samples to calculate error.

${ }^{\mathrm{z}}$ AUPDC values were calculated using the following formula: AUDPC $=\Sigma_{i<n}\left(\left[R_{i+1}+R_{i}\right] / 2\right)\left(t_{i+1}-t_{i}\right)$, where $\mathrm{R}_{i}=$ disease severity rating (percent leaf surface blighted) at the $i$ th observation, $t_{i}=$ time (days) since the previous rating at the $i$ th observation, and $n=$ total number of observations. In 1997, only treatments in fields B $(P=0.35)$ and $\mathrm{C}(P=0.74)$ were compared using a two-sided $t$ test, $P \leq$ 0.05 , using the 10 sampling stops per treatment per date to calculate the error. tion and Kamaran, 2002, 3-year versus 1year rotation; Table 2).

The impact of long rotation out of carrot on disease incidence, disease severity, and the number of required fungicide applications is shown for two fields on the same farm in 2001 (Fig. 3). In the field planted to carrot for two consecutive years, all three cultivars reached the $25 \%$ threshold in July, disease incidence reached over $90 \%$ during the season, disease severity ratings reached 6 for susceptible cv. Kamaran, and six fungicide applications were made (Fig. 3, arrows). In comparison, in the field with a rotation of over 20 years, the cultivars reached the $25 \%$ threshold in September, disease incidence never exceeded $60 \%$, disease severity ratings remained below 2, and only one fungicide spray was required (Fig. 3).

Differences were observed among cultivars in their susceptibility to leaf blights in commercial fields planted with two to four cultivars that received the same number of fungicide applications during the season (Table 3). The cvs. Bolero, Bergen, Eagle, and Carson were among the least susceptible, whereas Kamaran, Canada, and Recoleta were more susceptible based on comparisons of the average of the seasonlong disease severity ratings (Table 3 ). The AUDPC values also reflected these differences in susceptibility (Table 3). In general, carrot cultivars with marked differences in susceptibility reached the $25 \%$ disease incidence threshold at different times and required different numbers of fungicide applications.

\section{DISCUSSION}

The primary objective of this research was to develop an effective IPM program for fungal leaf blight diseases of carrot that is based on field scouting and the application of fungicides on an as-needed basis. The application of the $25 \%$ disease incidence threshold developed by Gillespie and Sutton $(11,32)$ has helped to effectively manage fungal leaf blight diseases in New York. Although the 25\% incidence threshold differs from more conservative thresholds used in other carrot-production regions in the United States $(2,6)$, delaying the first fungicide application until the $25 \%$ disease incidence threshold level was reached did not increase leaf blight incidence and severity or reduce carrot yields grown for processing compared with the plots in grower fields that were managed using a more conservative spray program. In addition, basing subsequent fungicide applications on scouting for increased leaf blight incidence and severity plus utilizing the local forecasted weather in conjunction with a 10- to 14-day spray interval were effective IPM strategies and, in many cases, reduced the total number of fungicide applications by as much as 83 to $100 \%$. Indeed by 1998 , only 1 year into the evaluation phase of the research, growers 
were becoming confident in the effectiveness of the carrot leaf blight IPM program and were coinciding fungicide applications in the "standard" grower plots exactly with those recommended for the IPM plots. When more sprays were applied by the growers, we found this was due to several reasons: the first spray was applied before the recommended threshold, fungicides were applied to all cultivars in a field even though only one cultivar had reached the threshold, copper materials had been used to manage bacterial blight, other vegetable production priorities competed on the farm, or any combination thereof. Adequate disease management currently is being achieved in Quebec using incidence thresholds even higher than $25 \%$ for early and late carrot (80 to 100 and $50 \%$, respectively; 4,5). For fresh market carrot cultivars, especially those marketed in bunches with their foliage, lower thresholds certainly will be required than for the processing carrot lines considered in this study.

The IPM program using a $25 \%$ incidence threshold developed for $A$. dauci $(11,32)$ also was effective in New York for managing leaf blight caused by $C$. carotae and when both $A$. dauci and $C$. carotae occur in the same field. In only one instance was there a negative impact on yield when using the IPM program, and this may have been due more to variability in soil, water drainage, or other factors common in large-scale production fields ( $>8.1$ ha). The use of Tom-Cast and other similar models as decision-support tools for applications of fungicides subsequent to the $25 \%$ incidence threshold in various carrot-growing regions has reduced the total number of fungicide applications during the season while maintaining crop productivity $(4,24)$. It also has limited the dependence on detailed weekly scouting. Tom-Cast is a weather-timed fungicide spray program for field tomato, a modified version of FAST, a forecast system for A. solani on tomato (19). Research trials in New York have indicated that using Tom-Cast can be effective for timing the application of needed fungicides after the initial spray is applied (G. Abawi, unpublished); however, the leaf wetness and temperature sensors must be placed within the carrot foliage in each scouted field and this may not be practical for carrot growers in New York at this time.

We documented that crop rotation was an important component of an IPM program for carrot fungal leaf blights. In New York, a 2-year rotation out of carrot is recommended to allow the thorough decomposition of any host crop residue that could serve as a source of overwintering inoculum (14), because the spores of $A$. dauci and $C$. carotae cannot persist free in the soil in the absence of host tissue (22). Increasing the length of rotation out of carrot delayed the date the cultivar reached the $25 \%$ disease incidence threshold and, therefore, reduced the number of fungicide applications during the season. However, cultivars in two fields with longer rotations out of carrot reached the threshold earlier than those with a shorter rotation. This may have resulted from planting contaminated or infected seed, which serve as a source of inoculum to initiate pathogen infection when the conditions are conductive for disease development (33); differences in field microclimates; or proximity to other fields. The occurrence of individual, severely infected plants in a field essentially free of other infected plants and well below the $25 \%$ incidence threshold provided anecdotal evidence of seedborne transmission in several scouted fields. Such plants were found to be infected primarily with either $C$. carotae or Xan- thomonas campestris pv. carotae, the causal agent of bacterial blight.

Planting resistant carrot cultivars proved to be an important component of the fungal leaf blight IPM program because they typically delayed the date when the disease threshold was reached, required fewer fungicide applications, and had lower disease severity. Differences in disease severity and AUDPC values for individual cultivars in the same year or between years was attributable to how early the cultivar reached the threshold in a particular field, the rotation history of the field, and the environmental conditions. Although, in New York, the processor may determine which cultivars are planted, a priori knowledge of cultivar susceptibility can be used to make more educated pest man-

Table 2. Impact of crop rotation on the date the $25 \%$ disease incidence threshold was reached and the number of recommended fungicide applications for different carrot cultivars grown in commercial fields in 2001, 2002, and 2004

\begin{tabular}{|c|c|c|c|}
\hline Cultivar, year & Years of rotation $^{x}$ & Date of thresholdy & IPM sprays $^{z}$ \\
\hline \multicolumn{4}{|l|}{ Bergen } \\
\hline 2001 & 0 & 23 July & 4 \\
\hline 2002 & 1 & 1 July & 3 \\
\hline 2004 & $\geq 2$ & 7 July & 3 \\
\hline 2001 & $\geq 2$ & 30 July & 3 \\
\hline 2002 & 3 & 12 August & 3 \\
\hline \multicolumn{4}{|l|}{ Bolero } \\
\hline 2001 & 0 & 23 July & 4 \\
\hline 2001 & 1 & 13 August & 3 \\
\hline \multicolumn{4}{|l|}{ Calgary } \\
\hline 2001 & $\geq 20$ & 23 September & 1 \\
\hline \multicolumn{4}{|l|}{ Canada } \\
\hline 2001 & $\geq 2$ & 30 July & 3 \\
\hline 2002 & 3 & 26 August & 2 \\
\hline \multicolumn{4}{|l|}{ Carson } \\
\hline 2001 & 0 & 27 August & 1 \\
\hline 2002 & 1 & 29 July & 4 \\
\hline 2002 & 1 & 13 August & 3 \\
\hline 2004 & $\geq 2$ & 7 July & 4 \\
\hline 2001 & $\geq 2$ & 13 August & 2 \\
\hline 2001 & $\geq 2$ & 26 September & 1 \\
\hline 2002 & 3 & 26 August & 2 \\
\hline 2001 & $\geq 20$ & 11 September & 1 \\
\hline \multicolumn{4}{|l|}{ Cupar } \\
\hline 2004 & $\infty$ & 16 August & 1 \\
\hline \multicolumn{4}{|l|}{ Eagle } \\
\hline 2001 & 1 & 20 August & 3 \\
\hline 2001 & $\geq 2$ & 26 September & 1 \\
\hline 2004 & 3 & 13 July & 6 \\
\hline \multicolumn{4}{|l|}{ Fontana } \\
\hline 2001 & $\geq 2$ & 9 July & 3 \\
\hline \multicolumn{4}{|l|}{ Kamaran } \\
\hline 2001 & 0 & 23 July & 4 \\
\hline 2001 & 0 & 7 August & 2 \\
\hline 2002 & 1 & 13 August & 3 \\
\hline 2001 & $\geq 2$ & 26 September & 1 \\
\hline 2002 & $\geq 3$ & 23 July & 1 \\
\hline \multicolumn{4}{|l|}{ Kathmandu } \\
\hline 2002 & 1 & 1 July & 6 \\
\hline \multicolumn{4}{|l|}{ Recoleta } \\
\hline 2002 & 3 & 19 August & 2 \\
\hline
\end{tabular}

${ }_{\mathrm{x}}$ Number of years the field was rotated out of carrot based on grower records; $\infty=$ no history of carrot cultivation.

${ }^{y}$ Date the cultivar reached the $25 \%$ leaf blight incidence threshold for applying the first fungicide spray. No fungicide sprays were applied prior to threshold. Year $(F=3.6, P=0.05)$ and rotation $(F=$ $3.8, P=0.07$ ) had a significant effect on the threshold date.

${ }^{\mathrm{z}}$ Number of fungicide sprays recommended based on the carrot leaf blight integrated pest management (IPM) program. Threshold date had a significant effect on the number of IPM sprays applied to each field $\left(\chi^{2}=6.4, P=0.01\right)$, rotation only had a suggestive effect $\left(\chi^{2}=2.3, P=0.12\right)$, and cultivar and year had little effect according to a Poisson regression. 

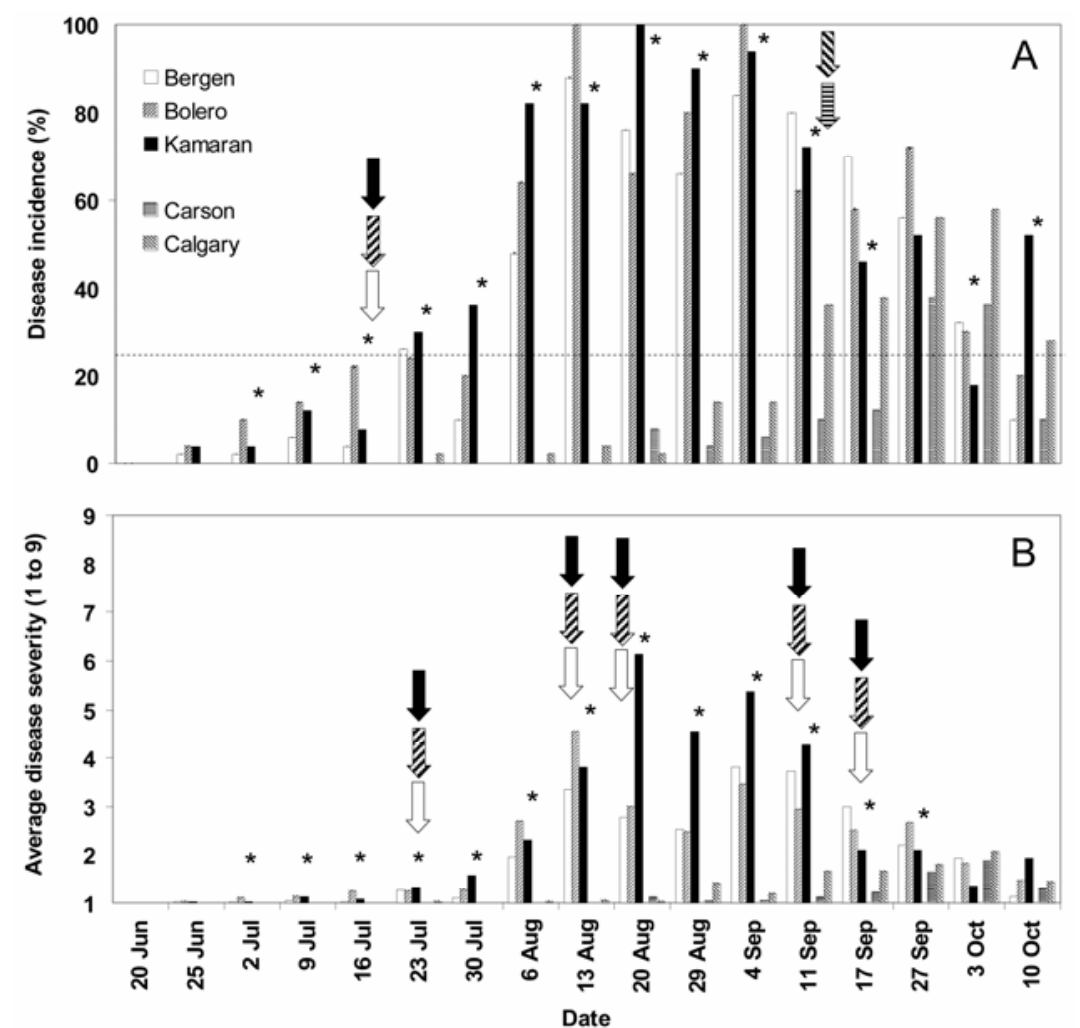

Fig. 3. Fungal leaf blight $\mathbf{A}$, incidence and $\mathbf{B}$, severity for two fields of one grower with either two consecutive years of carrot cultivation (cvs. Bergen, Bolero, and Kamaran) or a rotation of over 20 years (cvs. Carson and Calgary). Disease incidence (presence or absence of one or more lesions per leaf caused by Alternaria dauci, Cercospora carotae, or both) was determined by examining five leaves from five adjacent plants at 10 locations along a V-shaped transect in each plot of each field. The horizontal dotted line represents the $25 \%$ disease incidence threshold and the arrows indicate when fungicide applications were made to the corresponding cultivar based on disease $\mathbf{A}$, incidence or B, severity. Disease severity was rated on a scale of 1 to 9 based on the percentage of leaf surface symptomatic $(1=0 \%$ symptomatic to $9=$ over $50 \%)$. Asterisk indicates $P \leq 0.05$ for cultivars within each date according to a one-way analysis of variance.

Table 3. Average season-long leaf blight severity ratings and area under the disease progress curve (AUDPC) values for carrot cultivars evaluated in select commercial fields from 2001 to $2004^{\mathrm{x}}$

\begin{tabular}{|c|c|c|c|c|c|c|}
\hline Field & Year & Cultivar & $\begin{array}{l}\text { Average disease } \\
\text { severity }^{y}\end{array}$ & $P$ value & AUDPC $^{\mathbf{z}}$ & $P$ value \\
\hline \multirow[t]{2}{*}{1} & 2001 & Bolero & $1.57 \mathrm{a}$ & 0.0079 & $167 \mathrm{a}$ & 0.0106 \\
\hline & & Eagle & $1.70 \mathrm{~b}$ & $\ldots$ & $184 \mathrm{~b}$ & \\
\hline \multirow[t]{3}{*}{2} & 2001 & Bergen & $2.06 \mathrm{a}$ & $<0.0001$ & $228 \mathrm{a}$ & $<0.0001$ \\
\hline & $\ldots$ & Bolero & $2.16 \mathrm{a}$ & $\ldots$ & $239 a$ & $\ldots$ \\
\hline & & Kamaran & $2.57 \mathrm{~b}$ & $\ldots$ & $285 \mathrm{~b}$ & . \\
\hline \multirow[t]{3}{*}{3} & 2002 & Eagle & $2.08 \mathrm{a}$ & 0.0169 & $59 \mathrm{a}$ & 0.0850 \\
\hline & $\ldots$ & Bergen & $2.21 \mathrm{a}$ & $\ldots$ & $62 \mathrm{a}$ & $\ldots$ \\
\hline & $\ldots$ & Kamaran & $2.88 \mathrm{~b}$ & $\ldots$ & $77 \mathrm{a}$ & $\ldots$ \\
\hline \multirow[t]{4}{*}{4} & 2002 & Bergen & $1.44 \mathrm{a}$ & $<0.0001$ & $51 \mathrm{a}$ & $<0.0001$ \\
\hline & $\ldots$ & Carson & $1.71 \mathrm{a}$ & $\ldots$ & $61 \mathrm{a}$ & $\ldots$ \\
\hline & $\ldots$ & Canada & $2.88 \mathrm{~b}$ & $\ldots$ & $102 \mathrm{~b}$ & $\ldots$ \\
\hline & & Recoleta & $3.43 \mathrm{c}$ & $\ldots$ & $123 \mathrm{c}$ & $\ldots$ \\
\hline \multirow[t]{2}{*}{5} & 2002 & Carson & $2.97 \mathrm{a}$ & 0.0150 & $118 \mathrm{a}$ & 0.0051 \\
\hline & & Kamaran & $3.58 \mathrm{~b}$ & & $149 \mathrm{~b}$ & \\
\hline \multirow[t]{3}{*}{6} & 2003 & Eagle & $3.04 \mathrm{a}$ & $<0.0001$ & $109 a$ & $<0.0001$ \\
\hline & $\ldots$ & Carson & $3.37 \mathrm{a}$ & $\ldots$ & $122 \mathrm{a}$ & $\ldots$ \\
\hline & . & Canada & $6.23 \mathrm{~b}$ & $\ldots$ & $227 \mathrm{~b}$ & $\ldots$ \\
\hline \multirow[t]{3}{*}{7} & 2004 & Eagle & $3.43 \mathrm{a}$ & 0.0068 & $202 \mathrm{a}$ & 0.0006 \\
\hline & $\ldots$ & Carson & $3.87 \mathrm{~b}$ & $\ldots$ & $228 \mathrm{~b}$ & $\ldots$ \\
\hline & $\ldots$ & Kamaran & $4.06 \mathrm{~b}$ & $\ldots$ & $242 \mathrm{~b}$ & $\ldots$ \\
\hline
\end{tabular}

${ }^{x}$ Cultivars within the same field received the same number of fungicide applications, with the exception of an additional spray on cultivar Bergen in the 2002 field 2.

${ }^{y}$ Severity ratings ranged from 1 to 9 based on the percentage of leaf surface symptomatic $(1=0 \%$ symptomatic to $9=$ over $50 \%$ ). Means followed by the same letter within each field are not significantly different according to a two-sided $t$ test or Fisher's least significant difference $(P \leq 0.05)$.

${ }^{\mathrm{z}}$ Area under the disease progress curve (AUDPC) was calculated once the average severity rating in each field exceeded 1 (2001) or reached the 25\% disease incidence threshold (2002 to 2003). Means followed by the same letter within each field are not significantly different according to a two-sided $t$ test or Fisher's least significant difference $(P \leq 0.05)$. agement decisions. For instance, cultivars such as Fontana, Canada, and Kamaran that are more susceptible to Cercospora leaf blight could be planted in the same field to facilitate more efficient spray applications, because they may reach the $25 \%$ disease incidence threshold earlier than more resistant cultivars (such as Bergen, Bolero, and Carson).

Whereas growers formerly applied seven to eight fungicide applications for leaf blight disease management on processing carrot cultivars, beginning in midto late June and continuing through midSeptember, the adoption and implementation of IPM strategies by growers, as shown in this study, can significantly reduce the number of spray applications, sometimes up to $100 \%$. Based on our results and prior research, IPM for fungal leaf blights in New York consists of planting pathogen-free seed, two or more years of crop rotation, selecting cultivars with greater levels of resistance, blocking cultivars by susceptibility, weekly scouting each cultivar for disease incidence and severity, using a $25 \%$ disease incidence threshold to prompt the first fungicide spray, and applying subsequent fungicides based on increases in disease severity, weather forecasts, or spray interval. Similar IPM based programs have been developed for crops such as potato (28), cucumber (3), and sugar beet (36). The adoption of this IPM program by the growers will reduce fungicide use, improve fungal leaf blight disease management, and reduce production costs. Growers in general are interested in adopting IPM practices (16) and reducing fungicide applications, but they must be convinced that the diseases and their resultant losses are prevented by using IPM. Therefore, continued demonstration and outreach regarding the effectiveness of this IPM program for carrot leaf blights is necessary to promote its further adoption among New York carrot growers.

\section{ACKNOWLEDGMENTS}

This work was supported by the United States Department of Agriculture (USDA)/CSREES/IREE competitive grants program in pest management, RAMP project number 00-51101-9594-5110102207, and also in part by an NA PIAP project, number USDA-TPSU-CU-8103-1229. We thank J. Barnard for statistical assistance, J. W. Ludwig for technical assistance in research plot maintenance, C. L. MacNeil and A. C. McFaul of Cornell Cooperative Extension for assistance in the selection of commercial grower sites over the years, and the collaborating carrot growers for their interest and the use of their fields.

\section{LITERATURE CITED}

1. Angell, F. F., and Gabelman, W. H. 1964 Inheritance of resistance in carrot, Daucus carota var. sativa, to the leaf spot fungus, Cercospora carotae. J. Am. Soc. Hortic. Sci. 93:434437.

2. Ben-Noon, E., Shtienberg, D., Shlevin, E., and Dinoor, A. 2003. Joint action of disease control measures: a case study of Alternaria leaf blight of carrot. Phytopathology 93:1320-1328. 
3. Besse, C. E., Everts, K. L., and Linduska, J. J. 2001. Pesticide use and IPM practices for processing cucumbers. J. Veg. Prod. 7:33-44.

4. Boivin, G., Kushalappa, A. C., and Brodeur, L. 1990. Spatial dispersion and binomial sequential sampling plan for Cercospora carotae on carrots. Can. J. Plant Pathol. 12:209-212.

5. Boivin, G., and Sauriol, P. 1984. Rentabilite du depistage. Prod. Agric. 7:46-47.

6. Bounds, R. S., Hausbeck, M. K., and Podolsky, R. H. 2006. Comparing disease forecasters for timing fungicide sprays to control foliar blight on carrot. Plant Dis. 90:264-268.

7. Carisse, O., and Kushalappa, A. C. 1990. Development of an infection model for Cercospora carotae on carrot based on temperature and leaf wetness duration. Phytopathology 80:1233-1238.

8. Carroll, J. E., Chen, P., and Abawi, G. S. 2003. Demonstrating the effectiveness of an IPM program for the management of leaf blight diseases of carrots in New York. (Abstr.) Phytopathology 93:S14.

9. Farrar, J. J., Pryor, B. M., and Davis, R. M. 2004. Alternaria diseases of carrot. Plant Dis. 88:776-784.

10. Fry, W. E. 1982. Principles of Plant Disease Management. Academic Press, New York.

11. Gillespie, T. J., and Sutton, J. C. 1979. A predictive scheme for timing fungicide applications to control Alternaria leaf blight in carrots. Can. J. Plant Pathol. 1:95-99.

12. Gugino, B. K., and Abawi, G. S. 2005. Critical role of crop rotation in the management of leaf blight diseases of carrots in New York. (Abstr.) Phytopathology 95:S169.

13. Gugino, B. K., Abawi, G. S., and Ludwig, J. W. 2005. Updating the development of an IPM program for carrot leaf blight management in New York. Phytoprotection 86:138-139.

14. Gugino, B. K., Carroll, J. E., Chen, P., Ludwig, J. W., and Abawi, G. S. 2004. Carrot leaf blight diseases and their management in New York. Cornell Cooperative Extension IPM Disease Identification Sheet, Geneva, NY.

15. Gugino, B. K., Carroll, J. E., Widmer, T. L., Chen, P., and Abawi, G. S. Field evaluation of carrot cultivars for susceptibility to fungal leaf blight diseases in New York. Crop Prot. In press.

16. Hollingsworth, C. S., and Coli, W. M. 2001. IPM adoption in northeastern U.S.: an examination of the IPM continuum. Am. J. Alt. Agric. 16:177-183.

17. Hooker, W. J. 1944. Comparative studies of two carrot leaf diseases. Phytopathology 34:606-612.

18. Langenberg, W. J., Sutton, J. C., and Gillespie, T. J. 1977. Relation of weather variables and periodicities of airborne spores of Alternaria dauci. Phytopathology 67:879-883.

19. Madden, L., Pennypacker, S. P., and MacNab, A. A. 1978. FAST, a forecast system for Alternaria solani on tomato. Phytopathology 68:1354-1358.

20. Maude, R. B. 1966. Studies on the etiology of black rot, Stemphylium radicinum (Meier Drechsl. and Eddy) Neerg., and leaf blight Alternaria dauci (Kuhn) Groves and Skolko. on carrot crops and on fungicide control of their seed-borne infection phases. Ann. Appl. Biol. 63:287-294.

21. Netzer, D., and Kenneth, R. G. 1969. Persistence and transmission of Alternaria dauci (Kühn) Groves \& Skolko in semi-arid conditions of Israel. Ann. Appl. Biol. 63:289-294.

22. Pryor, B. M. 2002. Survival and persistence of Alternaria dauci in carrot cropping systems. Plant Dis. 86:1115-1122.

23. Raid, R. N. 2002 Cercospora leaf blight of carrot. Pages 18-19 in: Compendium of Umbelliferous Crop Diseases. R. M. Davis and R. N. Raid, eds. American Phytopathological Society, St. Paul, MN

24. Rogers, P. M., and Stevenson, W. R. 2006. Weather-based fungicide spray programs for control of two foliar diseases on carrot cultivars differing in susceptibility. Plant Dis. 90:358-364.

25. Rogers, P. M., Stevenson, W. R., James, R. V., and Rand, R. E. 2003. Evaluation of carrot cultivars and breeding selections to identify resistance to foliar blights-Hancock 2002. Biological and Cultural Tests Control of Plant Diseases (on-line) Report 18:V026. DOI: 10.1094/BC18. The American Phytopathologi- cal Society, St. Paul, MN

26. Rogers, P. M., Stevenson, W. R., James, R. V., and Rand, R. E. 2004. Evaluation of carrot cultivars and breeding selections to identify resistance to two foliar diseases-Hancock, WI 2003. Biological and Cultural Tests Control of Plant Diseases (on-line.) Report 19:V011. DOI: 10.1094/BC19. The American Phytopathological Society, St. Paul, MN.

27. Shaner, G., and Finney, R. E. 1977. The effect of nitrogen fertilization on the expression of slow-mildewing resistance in knox wheat. Phytopathology 67:1051-1056.

28. Stevenson, W. R. 1991. IPM for potatoes: a multifaceted approach to disease management and information delivery. Plant Dis. 77:309311.

29. Strandberg, J. O. 1977. Spore production and dispersal of Alternaria dauci. Phytopathology 67:1262-1266.

30. Strandberg, J. O. 1988. Establishment of Alternaria leaf blight on carrots in controlled environments. Plant Dis. 72:522-526.

31. Strandberg, J. O. 1992. Alternaria species that attack vegetable crops: Biology and options for disease management. Pages 175-208 in: Alternaria Biology, Plant Diseases and Metabolites. J. Chetkowski and A. Visconti, eds. Elsevier Science Publications, Amsterdam, The Netherlands.

32. Sutton, J. C., and Gillespie, T. J. 1983 Weather-times sprays for carrot blight control. Ontario Ministry of Agriculture and Food AGDEX 258/635.

33. Thomas, H. R. 1942. Cercospora blight of carrot. Phytopathology 33:114-125.

34. van Delden, A., and Carisse, O. 1993. Effect of plant age, leaf age and leaf position on infection of carrot leaves by Cercospora carotae. Phytoprotection 74:75-87.

35. Weingart, D. B., and Stivers, L. J. 1999. Crop Profile for Carrots in New York. Cornell Cooperative Extension, Ithaca, NY.

36. Wolf, P. F. J., and Verreet, J. A. 2002. An integrated pest management system in Germany for the control of fungal leaf diseases in sugar beet: the IPM sugar beet model. Plant Dis. 86:336-344. 